\title{
*1) 睡眠時無呼吸症候群
}

Editorial

トピックス

I . 睡眠時無呼吸症候群の病態

中山 秀章

1052

II. 睡眠時無呼吸症候群 (SAS) の疫学

佐藤 誠

1059

III. 睡眠時無呼吸症候群の診断

藤田 幸男・他

1066

IV. 睡眠時無呼吸症候群の治療
1. CPAP
渡部 良雄・他
1073
2. 閉塞性睡眠時無呼吸（OSA）におけるCPAP以外の治療
西島 嗣生・他 1082
V. 睡眠時無呼吸症候群と循環器疾患
葛西 隆敏
1089
VI. 睡眠時無呼吸症候群と交通事故
富田 康弘・他
1095
VII. CPAP遠隔モニタリングと睡眠医療連携
陳 和夫 

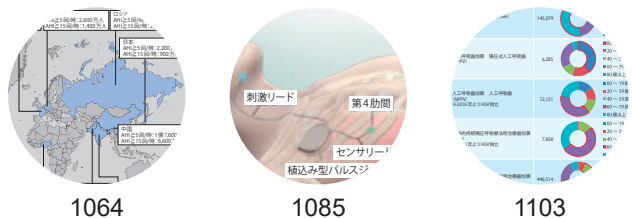

\section{シリーズ : 診療ガイドライン at a glance}

C型肝炎治療ガイドライン（第 7 版）

B型肝炎治療ガイドライン（第3.1版）

黒崎 雅之

1114

\section{今月の症例}

リツキシマブが有効であった

多発血管炎性肉芽腫症に伴う肥厚性硬膜炎の 1 例

平野 れな・他

1124

ドパミントランスポーターシンチグラフィで

線条体の集積低下を示した糖尿病性舞踏病の 1 例

新村 隼・他

1130

\section{医学と医療の最前線}

非遺伝性小脳性運動失調症の最前線一treatable cerebellar ataxia一

吉倉 延亮・他 1138

炎症性腸疾患の治療の最前線

仲瀬 裕志

1145

\section{專門医部会}

シリーズ：一目瞭然!目で診る症例

「一目瞭然! 目で診る症例」問題・解答

小野 亮平・他

1153

第 1 回「全人的医療実践ワークショップ」開催報告

内科医にとっての全人的医療とは?

土屋 静馬 ・他

1155

\section{内科学会からのお知らせ}

誌定医制度—認定更新単位取得に関する「2020年度セルフトレーニング問題」について 1164

講演会「「第117回日本内科学会講演会」開催にあたって

第 117 回日本内科学会講演会 概要

第117回日本内科学会講演会 日程表

生涯教育講演会及び内科学の展望の開催のご案内

JMECCからのお知らせ

試験情報

2021 年以降の専門医試験について（新制度）

研修単位取得の対象となる企画とその参加単位数

日本医師会生涯教育企画一覧 